\title{
Ocurrencia de Lasiodiplodia theobromae en Cattleya spp. en Corrientes, Argentina
}

\author{
María Graciela Cabrera ${ }^{1 ;}$ María Agueda Cúdom ${ }^{1}$
}

${ }^{1}$ Universidad Nacional del Nordeste, Facultad de Ciencias Agrarias, Fitopatología. Sargento Cabral 2131, CP 3400, Corrientes, Argentina. Autor para correspondência: María G. Cabrera (cabrera@agr.unne.edu.ar)

Data de chegada: 18/04/2012. Aceito para publicação em: 30/03/2013.

Cattleya es un género de orquídeas epífitas con más 113 especies, nativas desde Costa Rica hasta el Sur de América tropical. Desde el año 2008, en viveros e invernaderos en Corrientes (Argentina) se observaron manchas necróticas, reblandecidas y húmedas en tallos y pseudobuldos de Cattleya spp., síntomas característicos de pudrición húmeda. Las lesiones se presentaron inicialmente como áreas cloróticas, ascendentes por los bordes de las hojas. Estas se tornaron pardas hasta cubrir todo el órgano afectado (Figura 1A). En las raíces enfermas se observaron áreas de tejido parenquimatoso degradado, húmedo, pardo y con desprendimiento de corteza. Sobre el tejido enfermo se observaron estructuras globosas, subepidérmicas, de color negro, a partir de las cuales se liberaban cirros de esporas oscuras con aspecto de carbonilla humedecida (Figura 1B-C). En análisis preliminares de tejido enfermo se observaron picnidios característicos del orden Sphaeropsidales. Se sembraron en medio de agar papa glucosado (APG) al 1,5\%, pH 6 en cajas de Petri, trocitos de tejidos enfermos con síntomas, previamente lavados y desinfectados en hipoclorito de sodio al $2,5 \%$ durante $1 \mathrm{~min}$; las cajas se incubaron en estufa de cultivo a $24{ }^{\circ} \mathrm{C}$, durante 15 días, al cabo de los cuales se desarrollaron los cuerpos de fructificación de hongo en estudio.

En sustrato natural como en cultivo el hongo aislado produjo picnidios globosos, negros, aislados, de paredes gruesas (Figura 1 $\mathrm{B}, \mathrm{C})$. Se observó la formación interna de conidióforos hialinos, simples y cortos. Los conidios de forma elipsoide, son inicialmente unicelulares y hialinos y a la madurez se tornan a unitabicados y de color castaño oscuro. La pared es delgada con estrías longitudinales en la superficie. Miden de 28-32 $\mu \mathrm{m}$ x 12-17 $\mu \mathrm{m}$ (Figuras 1B, 1C y 1D).

Las características culturales y morfológicas son coincidentes con las descripciones de Punithalingan E. (1976), (Botryodiplodia theobromae. CMI. Descriptions of pathogenic fungi and bacteria. $\mathrm{n}^{\circ}$ 519; y Sutton B.C. (1980). The Coelomycetes. Fungi imperfecti with pycnidia, acervuli and stroma. CMI. Kew, Surrey, England). Sobre dicha base el hongo patógeno fue identificado como Lasiodiplodia theobromae (Pat.) Griff. \& Maubl.

Las pruebas de patogenicidad se realizaron con uno de los aislamientos en plantas de Cattleya sp. sanas. Para la inoculación, discos de micelio con estructuras reproductivas del hongo de 14 días de edad se dispusieron sobre hojas y tallos con y sin heridas. El tejido

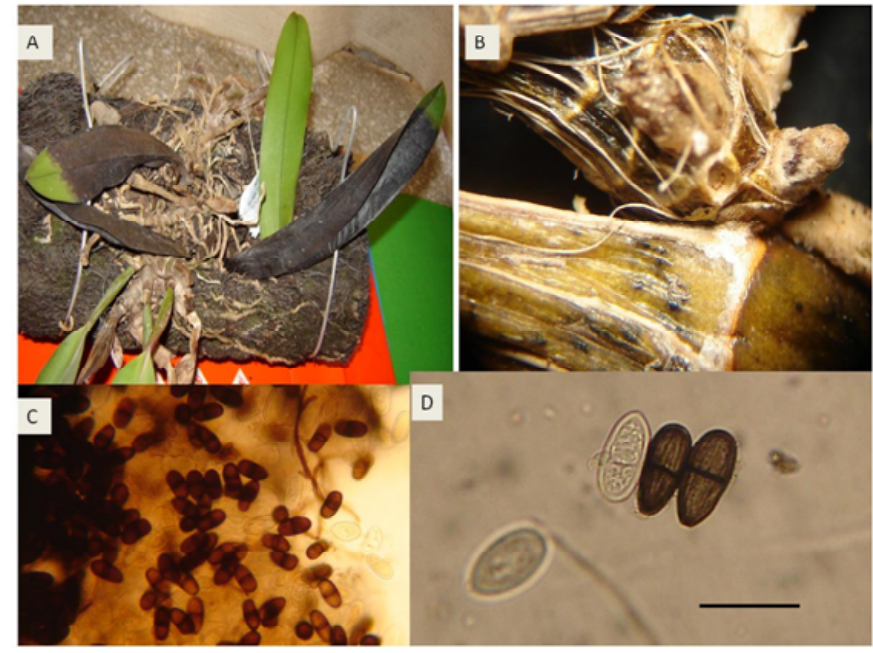

Figura 1. A. Síntomas en plantas de Cattleya sp. causados por Lasiodiplodia theobromae; B. Síntomas avanzados en tallo y formación de picnidios de L. theobromae. C. Picnidio liberando conidios. D. Conidios de $L$. theobromae en distintos grados de desarrollo. (Barra $30 \mu \mathrm{m}$ ).

inoculado se cubrió con algodón embebido en agua. Plantas sanas sin inocular se emplearon como control. Las plantas se embolsaron durante 72 horas. Pasado este tiempo, se retiró la bolsa y las plantas se mantuvieron bajo condiciones de invernadero a temperatura ambiente durante 10 días. En las plantas inoculadas, con o sin herida, se observaron síntomas similares a los apreciados en las orquídeas comerciales. Por último, se tomó muestra del tejido sintomático para identificar y reaislar el agente causal de la enfermedad. Este patógeno se caracterizó como L. theobromae basándose en las características morfológicas descritas previamente.

En Brasil, ya se reportó previamente la ocurrencia de L. theobromae como agente causal del tizón en Catasetum fimbratum (López et al. 2009. Australasian Plant Disease Notes 4:64). Con este reporte y lo encontrado en el presente estudio se estaría confirmando a $L$. theobromae como patógeno de algunas especies de la familia Orchidaceae. Sin embargo, cabe resaltar que éste es el primer reporte de L. theobromae como patógeno de Cattleya spp. en Argentina. 